\title{
Mineral Profile of Pito from Accra, Tamale, Bolgatanga and Wa in Ghana
}

\author{
G. O. Duodu ${ }^{1, *}$ E. O. Amartey ${ }^{2}$, A. B. Asumadu-Sakyi ${ }^{3}$, C. A. Adjei ${ }^{3}$, F. K. Quashie ${ }^{3}$, I. Nsiah-Akoto ${ }^{3}$, \\ G. Ayanu $^{4}$
}

\author{
${ }^{1}$ Radiological and Medical Sciences Research Institute, Ghana Atomic Energy Commission, Legon, P. O. Box LG 80, Ghana \\ ${ }^{2}$ National Data Centre, NNRI, Ghana Atomic Energy Commission, Legon, P. O. Box LG 80, Ghana \\ ${ }^{3}$ Nuclear Application Centre, NNRI, Ghana Atomic Energy Commission, Legon, P. O. Box LG 80, Ghana \\ ${ }^{4}$ Nuclear Chemistry and Environmental Research Centre, NNRI, Ghana Atomic Energy Commission, Legon, P. O. Box LG 80, Ghana
}

\begin{abstract}
This study was undertaken to investigate the mineral profile of pito, a traditionally brewed alcoholic beverage popularly consumed along West Coast of Africa. Pito samples from four cities in Ghana namely; Bolgatanga, Tamale, Wa and Accra were analysed for their metal content. Concentrations of $\mathrm{Na}, \mathrm{K}, \mathrm{Mn}, \mathrm{Cu}$ and $\mathrm{Zn}$, were measured in all the samples analysed. However, $\mathrm{Fe}, \mathrm{Ni}, \mathrm{Cd}$ and $\mathrm{Pb}$ recorded $70 \%, 83 \%, 58 \%$ and $79 \%$ incidence respectively in the samples, but $\mathrm{Cr}$ was measured below detection limit in all the samples. The concentrations of $\mathrm{Na}, \mathrm{K}, \mathrm{Mn}, \mathrm{Cu}, \mathrm{Zn}, \mathrm{Fe}, \mathrm{Ni}, \mathrm{Pb}$ and $\mathrm{Cd}$ recorded ranged between 15 to $66 \mathrm{mg} / \mathrm{L}, 581$ to $1108 \mathrm{mg} / \mathrm{L}, 0.152$ to $0.808 \mathrm{mg} / \mathrm{L}, 0.076$ to $0.308 \mathrm{mg} / \mathrm{L}, 0.456$ to $0.910 \mathrm{mg} / \mathrm{L}$, 0.308 to $2.832 \mathrm{mg} / \mathrm{L}, 0.040$ to $0.176 \mathrm{mg} / \mathrm{L}, 0.056$ to $0.272 \mathrm{mg} / \mathrm{L}$ and 0.011 to $0.048 \mathrm{mg} / \mathrm{L}$ respectively. With the exception of $\mathrm{Mn}$, all the essential minerals measured were below the recommended WHO maximum limits in water. Hence pito is a good source of $\mathrm{K}, \mathrm{Na}, \mathrm{Fe}, \mathrm{Cu}$ and $\mathrm{Zn}$. The detected concentrations of $\mathrm{Ni}, \mathrm{Pb}$ and $\mathrm{Cd}$ in the pito samples were however, above the respective maximum $\mathrm{WHO}$ guideline in water. Therefore pito is susceptible to metal contamination due to poor handling and primitive equipment used in the production and consumers should be apprehensive of the environs where the pito is prepared.
\end{abstract}

Keywords Pito, Mineral, Concentration, Guideline, Maximum Limit, Recorded

\section{Introduction}

Pito is a local traditionally brewed alcoholic beverage in some parts of West Africa including Ghana. It is produced mainly from the grains of guinea corn (Sorghum vulgare and Sorghum bicolor)[1] and/or millet. Sorghum is one of the most important crops in Africa, Asia and Latin Ameri$\mathrm{ca}[2,3]$. More than $35 \%$ of sorghum is grown directly for human consumption. The rest is used primarily for animal feed, alcohol production and industrial products[3,4,5,].

Pito is golden yellow to dark brown in colour with taste varying from slightly sweet to very sour and contains sugars, lactic acid, amino acids, 2-3\% alcohol, proteins and vitamins[6]. As described by[7], the process of production of burukutu involves washing of the grains, steeping, malting, mashing, wort extraction, fermentation and maturation. The microorganisms associated with fermentation include Saccharomyces cerevisiae, Saccharomyces chavelieria and Leuconostoc mesteroides. The process of pito production is similar to burukutu production except that, in pito produc-

* Corresponding author:

jogd14@yahoo.com (Godfred Odame Duodu)

Published online at http://journal.sapub.org/fph

Copyright (C) 2012 Scientific \& Academic Publishing. All Rights Reserved tion, the $\mathrm{pH}$ increases from about 4.2 to 6.2 within $24 \mathrm{~h}$ of fermentation and it decreases further to 3.7 after $48 \mathrm{~h}$ if different types of grains are used to brew it and no adjunct is added[8]. Geotrichum candidum and Lactobacillus species have been described to be responsible for souring pito[1].

Due to differences in wort extraction and fermentation processes, 4 types of pito namely, Nandom, Dargati, Togo and Kokomba are consumed in Ghana. Their peculiar differences and characteristics are described by Sefa-Dedeh et al, 1999. Pito is popularly consumed in the three northern regions and the Zongo communities (settlements of the northerners in the southern sector of Ghana) of Ghana, parts of Nigeria, and other parts of West Africa[9]. Due to the simplicity of production, availability of raw plant materials and abject poverty in these communities, pito brewing can provide an important source of income for otherwise cash-poor households in rural areas. In Ghana, Pito is not found bottled or canned, and, as a rule, is purchased directly from the household in which it is brewed. It is typically served in a calabash outside the producer's home where benches are sometimes provided.

Studies by Kolawole et al. 2007, looking at the nutritional composition and microbial analysis of pito found out that they contained mineral elements such as calcium, magnesium and iron that were essential for regulating and building 
the living cells and aid in fighting depression. Microorganisms such as Staphylococcus aureus, Esherichia coli, Bacillus subtilis, Streptococcus species, Proteus species, Rhizopus stolonifer, Aspergillus flavus, Aspergillus niger, Saccharomyce cerevisiae and Mucor species were also isolated from the samples. They explained that the presence of some these microorganisms in the samples may be attributed to poor handling during production. Some strains of E. coli can cause gastroenteritis and urinary tract infection as well as diarrhea in infant.

Due to the crude nature of production and poor handling during and after preparation, the elemental profile was carried out to ascertain the introduction of some metals into pito Assessment of nutritional quality and safety of food consumed by the public is an important tool for the development of nutritional and health policies in a nation[10].

Humans are exposed to metals by ingestion through drinking or eating, by inhalation through breathing or by absorption through the skin when they come in contact with humans during our daily activities in agricultural, pharmaceutical, industrial or residential settings among others[11]. According to World Health Organization (WHO, 1995), research estimates from various countries indicate that the major sources of heavy metals for non-occupationally exposed adults are from food and drink. Also industrial activities and products that expose humans to heavy metal toxins include the manufacturing of pesticides, batteries, alloys, electroplated metal parts, textile dyes, steel among others[12].

Heavy metals such as lead $(\mathrm{Pb})$, mercury $(\mathrm{Hg})$, cadmium (Cd) and arsenic (As) are generally regarded as environmental contaminants and their presence in foods or drinks can have some toxic effects on human. High levels of $\mathrm{Pb}$ in foods may result to food poisoning in humans either in acute or chronic exposure. Accumulation of lead produces damaging effects in the hematopoetical, hematic, renal, gastrointestinal systems[13,14]. Zinc plays a role as an integral part of a number of metalloenzymes and as a catalyst for regulating the activity of over 300 specific zinc-depended enzymes[15]. The role that copper plays in anemia is related to the mobilization of the tissue iron, the formation of the mitochondrial heme, and the reduction of erythrocyte half-life[16]. Both copper deficiency and excess result in anemia[17]. Copper has no pro-oxidant activity at a considerably higher intake[18]. Diets low in copper are suggested as an explanation for much of the epidemiology and patho-physiology of ischemic heart disease[19]. However, the presence of $\mathrm{Cu}$ and $\mathrm{Zn}$ in foods has both nutritional and toxic effects in humans.

\section{Sampling and Analysis}

Pito samples were bought from four different cities Tamale, Wa, Bolgatanga and Accra between February and March 2011. Six (6) samples each were taken from all the cities except Accra where only 3 were taken. The three ci- ties Bolgatanga, Tamale and Wa were chosen due to the unique method of preparation and popularity of consuming pito. The 3 sampling sites in Accra reflect the preparation method in the 3 cities above. All 21 samples were collected, put separately into acid cleaned high-density $1 \mathrm{~L}$ polyethylene sampling bottles and analyzed according to strict sampling protocols described by[20]. The samples were transported in ice cooler on ice and stored at $-4^{0} \mathrm{C}$, prior to analysis. Chemical analyses on the samples were conducted using standard procedures recommended by[21]. Analysis of $\mathrm{Na}^{+}$and $\mathrm{K}^{+}$ion concentrations were done using a Sherwood model 420 flame photometer. Samples for trace metal analysis were acidified to $\mathrm{pH}<2$ with $10 \%$ analytical grade $\mathrm{HNO}_{3}$. They were then acid digested using an ETHOS 500 model microwave and read using Varian AA240FS model Atomic Absorption Spectrophotometer in an air-acetylene flame at the Nuclear Chemistry and Environmental Research Centre, Ghana Atomic Energy Commission. Analytical grade reagents were used for all analysis and replicate measurements were done to ensure reproducibility and good quality control.

Positive Control: Single element e.g. $\mathrm{Cd}, \mathrm{Cu}, \mathrm{Pb}$, and $\mathrm{Fe}$ reference standard samples (Spectrascan, Sweden) standard reference material included in the analysis were treated as a sample as described above. These served as internal positive control sample.

\section{Results and Discussions}

From figure 1, potassium measured the highest concentration in all the pito samples. The general trend of the trace metals concentration were in the order; $\mathrm{K}>\mathrm{Na}>\mathrm{Zn}>\mathrm{Fe}>$ $\mathrm{Mn}>\mathrm{Pb}>\mathrm{Ni}>\mathrm{Cu}>\mathrm{Cd}>>\mathrm{Cr}$. Relatively, $\mathrm{Pb}$ which is a toxic trace metal measured almost the same concentrations in the samples from Tamale,Wa and Accra with Bolgatanga recording a lower concentration. $\mathrm{Cr}$ which is also a potentially toxic element in the $\mathrm{Cr}^{3+}$ state had concentrations below detection limits in all the samples. These toxic trace metals may have been introduced during handling and production of the pito. Interestingly, $\mathrm{Na}, \mathrm{K}, \mathrm{Fe}, \mathrm{Zn}, \mathrm{Mn}, \mathrm{Cu}$ and $\mathrm{Ni}$ which are all essential elements measured relatively higher concentrations, thus indicating that consumption of pito could be a good source of supplement of these trace metals.

The mean concentrations of $\mathrm{K}$ are $750.50 \pm 90.25$, $942.67 \pm 176.97, \quad 694.75 \pm 117.50$ and $790.00 \pm 9.19 \mathrm{mg} / \mathrm{L}$ whilst those of $\mathrm{Na}$ are $21.75 \pm 12.20,28.33 \pm 9.71$, $60.25 \pm 4.19$ and $25.50 \pm 3.54 \mathrm{mg} / \mathrm{L}$ recorded at Bolgatanga, Tamale, Wa and Accra respectively. The lowest $\mathrm{K}$ concentration measured was $581 \mathrm{mg} / \mathrm{L}$ (Table 3 ) and the highest being $1108 \mathrm{mg} / \mathrm{L}$ (Table 2) recorded at Wa and Tamale respectively. The lowest $\mathrm{Na}$ concentration was $15 \mathrm{mg} / \mathrm{L}$ (Table 1) with the highest being $66 \mathrm{mg} / \mathrm{L}$ (Table 3 ) also recorded at Bolgatanga and Wa respectively (Table 1 and 3). Potassium and sodium are macro-minerals required for the maintenance of cellular water balance, acid-base balance and nerve transmission and are required in large amounts in the 
body[22,23]. Deficiencies of these macronutrients lead to muscle cramps, mental confusion, loss of appetite and irregular cardiac rhythm[23]. However, there is a direct relationship between sodium intake and hypertension in humans[24]. Therefore it is desirable that the concentration of sodium in foods is not as high as that of potassium. These results therefore indicate a desirability of the consumption of pito because they contain high concentrations of sodium and potassium but the concentration of sodium is lower than that of potassium.

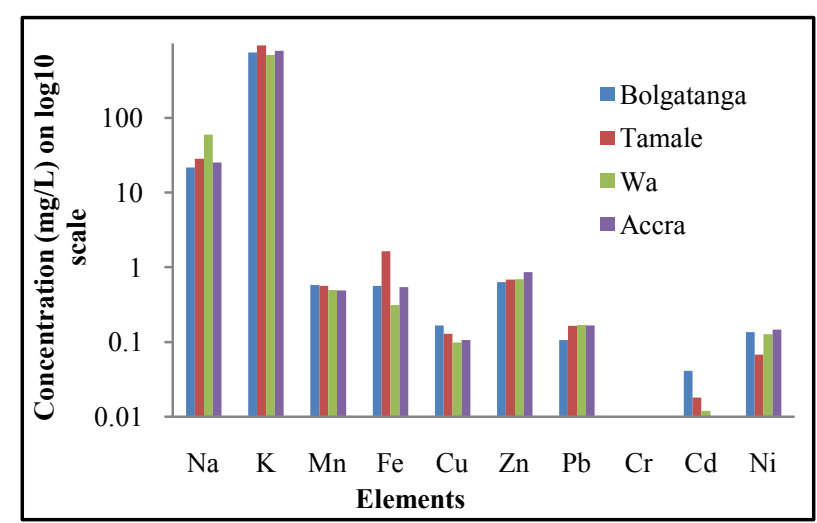

Figure 1. trace element concentrations in the pito samples from the various cities

Table 1. Concentration of elements $(\mathrm{mg} / \mathrm{L}$ or $\mathrm{ppm})$ in pito samples from Bolgatanga

\begin{tabular}{ccccc}
\hline Element (mg/L) & $\mathbf{n}$ & Mean & Interval & STD DEV \\
\hline $\mathbf{N a}$ & 6 & 21.75 & $15-40$ & 12.203 \\
$\mathbf{K}$ & 6 & 750.5 & $629-824$ & 90.253 \\
$\mathbf{M n}$ & 6 & 0.583 & $0.420-0.792$ & 0.19 \\
$\mathbf{F e}$ & 3 & 0.568 & $0501-0.660$ & 0.33 \\
$\mathbf{C u}$ & 6 & 0.166 & $0.112-0.308$ & 0.095 \\
$\mathbf{Z n}$ & 6 & 0.636 & $0.456-0.868$ & 0.173 \\
$\mathbf{P b}$ & 5 & 0.106 & $0.088-0.124$ & 0.018 \\
$\mathbf{C r}$ & 0 & $<0.001$ & & \\
$\mathbf{C d}$ & 6 & 0.041 & $0.032-0.048$ & 0.007 \\
$\mathbf{N i}$ & 5 & 0.135 & $0.108-0.172$ & 0.034 \\
\hline
\end{tabular}

$\mathrm{n}=$ Total number of samples analysed in this city (6). However values lower than this under this column means that in such instance the element concentration in those samples are below the detection limit for the analytical technique applied. Hence, these values were not used in the statistical analysis.

Table 2. Concentration of elements ( $\mathrm{mg} / \mathrm{L}$ or $\mathrm{ppm})$ in pito samples from Tamale

\begin{tabular}{ccccc}
\hline Element (mg/L) & $\mathbf{n}$ & Mean & Interval & STD DEV \\
\hline $\mathbf{N a}$ & 6 & 28.333 & $20-39$ & 9.713 \\
$\mathbf{K}$ & 6 & 942.667 & $756-1108$ & 176.967 \\
$\mathbf{M n}$ & 6 & 0.563 & $0.152-0.808$ & 0.358 \\
$\mathbf{F e}$ & 5 & 1.648 & $0.464-2.832$ & 1.674 \\
$\mathbf{C u}$ & 6 & 0.129 & $0.096-0.176$ & 0.042 \\
$\mathbf{Z n}$ & 6 & 0.683 & $0.580-0.776$ & 0.098 \\
$\mathbf{P b}$ & 5 & 0.164 & $0.056-0.272$ & 0.153 \\
$\mathbf{C r}$ & 0 & $<0.001$ & & \\
$\mathbf{C d}$ & 5 & 0.018 & $0.012-0.024$ & 0.008 \\
$\mathbf{N i}$ & 5 & 0.068 & $0.040-0.096$ & 0.040 \\
\hline
\end{tabular}

The mean concentrations of $\mathrm{Mn}$ were $0.583 \pm 0.19$, $0.563 \pm 0.358,0.498 \pm 0.158$ and $0.488 \pm 0.065 \mathrm{mg} / \mathrm{L}$ recorded at at Bolgatanga, Tamale, Wa and Accra respectively. The highest concentration of $0.808 \mathrm{mg} / \mathrm{L}$ (Table 1) exceeds the
WHO (2006) guideline of $0.4 \mathrm{mg} / \mathrm{L}[25]$ while the lowest, $0.158 \mathrm{mg} / \mathrm{L}$ (Table 1) also exceeded the EU (1998) guideline of $0.05 \mathrm{mg} / \mathrm{L}[26]$ in drinking water. $\mathrm{Mn}$ is an essential element for animals. Deficiencies of Mn result in severe skeletal and reproductive abnormalities in mammals. It is widely distributed throughout the body with little variation and does not accumulate with age[27].

Table 3. Concentration of elements $(\mathrm{mg} / \mathrm{L}$ or $\mathrm{ppm})$ in pito samples from Wa

\begin{tabular}{ccccc}
\hline Element $(\mathbf{m g} / \mathbf{L})$ & $\mathbf{n}$ & Mean & Interval & STD DEV \\
\hline $\mathbf{N a}$ & 6 & 60.250 & $56-66$ & 4.193 \\
$\mathbf{K}$ & 6 & 694.750 & $581-856$ & 117.503 \\
$\mathbf{M n}$ & 6 & 0.498 & $0.320-0.696$ & 0.158 \\
$\mathbf{F e}$ & 3 & 0.312 & $0.308-0.315$ & 0.180 \\
$\mathbf{C u}$ & 6 & 0.099 & $0.076-0.116$ & 0.020 \\
$\mathbf{Z n}$ & 6 & 0.694 & $0.572-0.820$ & 0.124 \\
$\mathbf{P b}$ & 3 & 0.168 & $0.096-0.240$ & 0.102 \\
$\mathbf{C r}$ & 0 & $<0.001$ & & \\
$\mathbf{C d}$ & 3 & 0.012 & $0.011-0.012$ & 0.001 \\
$\mathbf{N i}$ & 4 & 0.127 & $0.044-0.176$ & 0.072 \\
\hline
\end{tabular}

The concentration of $\mathrm{Fe}$ ranged between 0.308 to $2.832 \mathrm{mg} / \mathrm{L}$. The highest concentration was recorded at Tamale (Table 2) with the lowest recorded at Wa (Table 3). Fe is an essential element in human diet and is found in natural fresh waters at levels ranging from 0.5 to $50 \mathrm{mg} / \mathrm{L}$. Estimates of the minimum daily requirement for iron depend on age, sex, physiological status and iron bioavailability and range from about 10 to $50 \mathrm{mg} /$ day[25]. It forms part of haemoglobin, which allows oxygen to be carried from the lungs to the tissues. Severe Fe deficiency causes anaemia in humans.

The concentrations of $\mathrm{Cu}$ in the pito samples analysed were low compared to other essential minerals. $\mathrm{Cu}$ concentrations ranged from 0.076 to $0.308 \mathrm{mg} / \mathrm{L}$, with the highest and lowest concentrations measured at Bolgatanga (Table 1) and Wa (Table 3) respectively. Moreover, the highest concentration of $0.308 \mathrm{mg} / \mathrm{L}$ measured was below WHO (2006) guideline of $2 \mathrm{mg} / \mathrm{L}$ in drinking water (Table 5). Hence pito will not be a good source of $\mathrm{Cu}$. $\mathrm{Cu}$ is an essential part of several enzymes and it is necessary for the synthesis of haemoglobin[28].

The lowest concentration of $\mathrm{Zn} 0.456 \mathrm{mg} / \mathrm{L}$ was measured at Bolgatanga (Table 1) whiles the highest concentration $0.910 \mathrm{mg} / \mathrm{L}$ was measured at Accra (Table 4). Though the WHO 1993 Guidelines for drinking water concluded that the derivation of a guideline value is not required, drinking-water containing zinc at levels above $3 \mathrm{mg} / \mathrm{L}$ may not be acceptable to consumers[25]. Therefore, the concentrations of $\mathrm{Zn}$ in the pito samples are acceptable for consumers. $\mathrm{Zn}$ is an essential trace metal for both animals and humans. A deficiency of zinc is marked by retarded growth, loss of taste and hypogonadism, leading to decreased fertility[27]. $\mathrm{Zn}$ toxicity is rare but, at concentrations in water up to $40 \mathrm{mg} / \mathrm{kg}$, may induce toxicity, characterized by symptoms of irritability, muscular stiffness and pain, loss of appetite, and nausea[29].

Ni recorded very low concentrations in the pito samples 
relative to the other heavy metals apart from $\mathrm{Cd}$ which recorded the lowest concentration relatively. The concentrations of $\mathrm{Ni}$ in the samples ranged between $<0.01$ to $0.176 \mathrm{mg} / \mathrm{L}$. The highest concentration, $0.176 \mathrm{mg} / \mathrm{L}$ was measured at Wa (Table 3) with the lowest detectable concentration, $0.040 \mathrm{mg} / \mathrm{L}$ recorded at Tamale (Table 2). The concentration of $\mathrm{Ni}$ in 2 samples from Wa (Table 3) and a sample each from Bolgatanga and Tamale (Table 1and 2) were below the detection limit of $0.01 \mathrm{mg} / \mathrm{L}$ of the analytical method used. The WHO (2006) guideline for Ni in drinking water is $0.02 \mathrm{mg} / \mathrm{L}$ (Table 5). Thus the concentrations of $\mathrm{Ni}$ detected in all the samples were far above the stipulated limit. The major source of $\mathrm{Ni}$ for humans is food and uptake from natural sources, as well as food processing[30]. Increased incidence of cancer of the lung and nasal cavity caused by high intake of $\mathrm{Ni}$ has been also been reported in workers of Ni smelters[28].

Table 4. Concentration of elements $(\mathrm{mg} / \mathrm{L}$ or $\mathrm{ppm})$ in pito samples from Accra

\begin{tabular}{ccccc}
\hline Element (mg/L) & $\mathbf{n}$ & Mean & Interval & STD DEV \\
\hline $\mathbf{N a}$ & 3 & 25.500 & $22-29$ & 3.536 \\
$\mathbf{K}$ & 3 & 790.500 & $782-797$ & 9.192 \\
$\mathbf{M n}$ & 3 & 0.488 & $0.449-0.546$ & 0.065 \\
$\mathbf{F e}$ & 3 & 0.544 & $0.527-0.560$ & 0.023 \\
$\mathbf{C u}$ & 3 & 0.107 & $0.096-0.117$ & 0.013 \\
$\mathbf{Z n}$ & 3 & 0.859 & $0.815-0.910$ & 0.058 \\
$\mathbf{P b}$ & 3 & 0.166 & $0.111-0.223$ & 0.076 \\
$\mathbf{C r}$ & 0 & $<0.001$ & & \\
$\mathbf{C d}$ & 0 & $<0.002$ & & \\
$\mathbf{N i}$ & 3 & 0.146 & $0.125-0.168$ & 0.031 \\
\hline
\end{tabular}

Table 5. A comparison of metal concentration range $(\mathrm{mg} / \mathrm{L})$ in all samples with WHO maximum limit in drinking water

\begin{tabular}{ccc}
\hline Element & $\begin{array}{c}\text { Detected concentration } \\
\text { range }(\mathbf{m g} / \mathbf{L})\end{array}$ & $\begin{array}{c}\text { Maximum limit } \\
\text { WHO (2006) }\end{array}$ \\
\hline $\mathbf{N a}$ & $15-66$ & $\mathrm{NA}$ \\
$\mathbf{K}$ & $581-1108$ & $\mathrm{NA}$ \\
$\mathbf{M n}$ & $0.152-0.808$ & 0.4 \\
$\mathbf{F e}$ & $0.308-2.832$ & $\mathrm{NA}$ \\
$\mathbf{C u}$ & $0.076-0.308$ & 2 \\
$\mathbf{Z n}$ & $0.456-0.910$ & 3 \\
$\mathbf{P b}$ & $0.056-0.272$ & 0.01 \\
$\mathbf{C r}$ & $<0.001$ & $\mathrm{NA}$ \\
$\mathbf{C d}$ & $0.011-0.048$ & 0.003 \\
$\mathbf{N i}$ & $0.040-0.176$ & 0.02 \\
\hline
\end{tabular}

$\mathrm{NA}=$ Not available

The presence $\mathrm{Pb}$ in foods can have some toxic effects in human. $\mathrm{Pb}$ concentrations ranged from $<0.01$ to $0.272 \mathrm{mg} / \mathrm{L}$, with the highest and lowest detectable concentrations of $0.272 \mathrm{mg} / \mathrm{L}$ and $0.056 \mathrm{mg} / \mathrm{L}$ respectively recorded at Tamale (Table 2). However, $\mathrm{Pb}$ was not detected in 3 samples from Wa (Table 3) and a sample each from Bolgatanga and Tamale (Table 1 and 2). All the concentratins of $\mathrm{Pb}$ detected in the pito samples were far above the WHO (2006) guideline of $0.01 \mathrm{mg} / \mathrm{L}$ (Table 5) in drinking water. $\mathrm{Pb}$ is a cumulative poison and long-term exposure may cause kidney damage, anemia, nerve and brain damage, and even death.

$\mathrm{Cd}$ is classified as one of the most toxic heavy metals. The lowest detectable concentration of $\mathrm{Cd}, 0.011 \mathrm{mg} / \mathrm{L}$ was measured at Wa (Table 3) while the highest concentration,
$0.048 \mathrm{mg} / \mathrm{L}$ was measured at Bolgatanga (Table 1). Cd was not detected in all pito samples from Accra (Table 4), 3 samples from Wa (Table 3) and a sample from Tamale (Table 2). The detected concentrations of $\mathrm{Cd}$ in all the pito samples, however, were far above the WHO (2006) guideline of $0.003 \mathrm{mg} / \mathrm{L}$ (Table 5) in drinking water. Food is the main source of daily exposure to cadmium. Severe toxic symptoms resulting from $\mathrm{Cd}$ ingestion are reported between 10 to $326 \mathrm{mg}$ [27]. Fatal ingestions of $\mathrm{Cd}$, producing shock and acute renal failure, occur from ingestions exceeding $350 \mathrm{mg}[31]$.

\section{Conclusions}

The mineral profile of pito samples indicates the presence of both essential and toxic metals. With the exception of $\mathrm{Mn}$, all the essential minerals measured were below the recommended maximum limits. Hence pito is a good source of $\mathrm{K}, \mathrm{Na}, \mathrm{Fe}, \mathrm{Cu}$ and $\mathrm{Zn}$. The detected concentrations of $\mathrm{Ni}$, $\mathrm{Pb}$ and $\mathrm{Cd}$ in the pito samples were above the respective maximum guideline. However, not all the pito samples analysed were these metals found. Therefore the introduction of these toxic metals in pito could be attributed to poor handling during preparation or the utensils used for the production and not from the raw materials (grains) used. Further studies need to be done on the brewing utensils and the possible reactions that can occur between pito and the utensils. But more importantly, consumers should be apprehensive of the environs where the pito is prepared. The results can be used to evaluate the possible health risk associated with the consumption of pito.

\section{ACKNOWLEDGEMENTS}

The authors wish to acknowledge the Nuclear Chemistry and Environmental Research Centre, National Nuclear Research Institute, Ghana Atomic Energy Commission for making available the equipment and materials for the analysis.We express our profound gratitude to Miss Lebene Kpatah, Mr. Nash .O. Bentil and Mr.Michael Tawiah for assisting in the laboratory analysis of the samples.

\section{REFERENCES}

[1] Kolawole, O. M., Kayode, R. M. O. and Akinduyo, B. Proximate and microbial analyses of burukutu and pito produced in Ilorin, Nigeria. African Journal of Biotechnology Vol. (5), pp. 587-590, 5 March 2007

[2] Anglani C, 1998, Sorghum for human food: a review. Plant Foods Hum. Nutr. 52: 85-89

[3] Mamoudou H. Dicko, Harry Gruppen, Alfred S. Traoré, Alphons G. J. Voragen and Willem J. H. van Berkel. Sorghum grain as human food in Africa: relevance of content of starch and amylase activities. African Journal of Biotech- 
nology Vol. 5 (5), pp. 384-395, 1 March 2006

[4] Food and Agricultural Organization (FAO), 1995, Sorghum and millet in human nutrition. FAO Food and Nutrition Series No. 27. ISBN 92-5- 103381-1. Consulted on 10 September 2005 at:http://www.fao.org/DOCREP/T0818e/T0818E00.htm\#Co ntentsAwika JM, Rooney LW, 2004. Sorghum phytochemicals and their potential aspects on human health. Phytochemistry. 65:1199-1221

[5] Sefa-Dedeh, S., Sanni, A.I., Tetteh, G. and Sakyi-Dowson, E., 1999. Yeasts in the traditional brewing of pito in Ghana. World Journal of Microbiology \& Biotechnology 15: 593-597

[6] Ekundayo JA, 1969. The production of Burukutu. A Nigeria fermented Beverage. J. Food Technol. 4:217-225

[7] Asiedu JJ, 1989. Processing Tropical Crops. A Technological Approach, Macmillian Education Ltd. pp. 189-222

[8] WHO (World Health Organization), 2004. Global Status Report on Alcohol 2004

[9] Shittu T.A., Badmus B.A.. Statistical correlations between mineral element composition, product information and retail price of powdered cocoa beverages in Nigeria. Journal of Food Composition and Analysis 22 (2009) 212-217

[10] Ekpo, K.E., I.O. Asia, K.O. Amayo and D.A. Jegede, 2008. Determination of lead, cadmium and mercury in surrounding water and organs of some species of fish from Ikpoba river in Benin city, Nigeria, Int. J. Phy. Sc., 3(11): 289-292

[11] International Occupational Safety and Health Information Centre, 1999

[12] Correia, P.R.M., Oliveira, E., Oliveira, P.V., 2000. Simultaneous determination of $\mathrm{Cd}$ and $\mathrm{Pb}$ in foodstuffs by electrothermal atomic absorption spectrometry. Analytica Chimica Acta 405, 205-211

[13] Baht, R.V., Moy, G.G., 1997. Monitoring and assessment of dietary exposure to chemical contaminants. WHO, Geneva. Technical Report, 50, 132-149.

[14] McCall, K.A., Huang, C., Fierke, C.A., 2000. Function o and mechanism of zinc metalloenzymes. Journal of Nutrition 130, 1437-1446

[15] Conrad, M., Umbreit, J., 2000. Iron absorption and transport an update. American Journal of Hematology 64, 287-298

[16] Ramirez-Cardenas, L., Costa, N.M.B., Reis, F.P., 2005. Copper-iron metabolism interaction in rats. Nutrition Research 25, 79-92

[17] Rock, E., Mazur, A., O’Connor, J.M., Bonham, M.P., Rayssiguier, Y., Strain, J.J., 2000. The effect of copper supple- mentation on red blood cell oxidizability and plasma antioxidants in middle-aged healthy volunteers. Free Radical Biology and Medicine 28, 324-329

[18] Klevay, L.M., 2000. Trace element and mineral nutrition in disease: ischemic heart disease. In: Bogden, J.D., Klevay, L.M. (Eds.), Clinical Nutrition of the Essential Trace Elements and Minerals: The Guide for Health Professionals. Humana Press Inc., Totowa, NJ, pp. 251-271

[19] Gale, I.N. and N.S. Robins, 1989. The sampling and monitoring of groundwater quality. British Geological Survey, Hydrogeology Report No. 89/37

[20] APHA, 1998. Standard method for the examination of water and wastewater (20th Ed) Washington: American Public Health Association

[21] Wardlaw GM, 1999. Perspectives in nutrition. (4th edn.). Mc Graw-Hill Companies, USA., p. 532

[22] Worthington-Roberts B, 2007. Human nutrition. Microsoft Student 2008 [DVD]. Microsoft Corporation

[23] Dahl, 1972. Salt and hypertension. Am. J. Clin. Nutr. pp.25 238

[24] WHO (World Health Organization), 2006. Guidelines for Drinking Water Quality, Vol. 1, 3rd edition incorporating 1st and 2nd addenda WHO, Geneva, pp: 296-460

[25] Lenntech B.V, 1998-2011. WHO/EU drinking water standards comparative table. Assessed on 1st September 2011 at:http://www.who-eu-water-standards.htm

[26] Sivapermal, P., J.V. Sankar and P.G. Nair Viswanathan, 2007. Heavy metal concentrations in fish, shellfish and fish products from internal markets of India visà- vis international standards. Food Chem., 102: 612-620

[27] Anim, A.K., Ahialey, E.K., Duodu, G.O. Ackah, M. and Bentil, N.O., 2011. Accumulation Profile of Heavy Metals in Fish Samples from Nsawam, Along the Densu River, GhanaResearch Journal of Environmental and Earth Sciences 3(1): 56-60.

[28] NAS-NRC, 1974. National Academy of Sciences-National Research Council, Food and Nutrition Board, Recommended Dietary Allowances. 8th Edn., National Academy Press, Washington D.C.

[29] NAS-NRC, 1975. National Academy of Sciences-National Research Council, Division of Medical Sciences, Medical and Environmental Effects of Pollutants Nickel. National Academic Press, Washington D.C.

[30] NAS-NRC, 1982. National Academy of Sciences-National Research Council, Drinking Water and Health, National Academic Press, Washington D.C 